\title{
Spectroelectrochemistry of Enargite III: Alkaline Sulfide Leaching
}

R.N. Gow ${ }^{1}$, C Young ${ }^{1}$, H Huang ${ }^{1}$, G Hope ${ }^{2}$

\author{
${ }^{1}$ Montana Tech of The University of Montana; 1300 W. Park; Butte, MT, 59701, USA \\ ${ }^{2}$ Griffith University; 170 Kessels Road, Nathan, Qld, Australia, 4111
}

Keywords: Enargite, Arsenic, Raman Spectroscopy, Cyclic Voltammetry, Alkaline Sulfide

\begin{abstract}
The reactivity of an enargite mineral electrode was investigated spectroelectrochemically under conditions typically found in alkaline sulfide leach solutions at $\mathrm{pH} 11-13$ and $\mathrm{Na}_{2} \mathrm{~S}$ additions of 50 and $250 \mathrm{~g} \mathrm{~L}^{-1}$. A bulk enargite electrode was cycled between 0 and $-1000 \mathrm{mV}$ for each set of solution conditions. Raman spectroscopy was used to determine and compare surface formations against species in mass-balanced $\mathrm{E}_{\mathrm{H}-\mathrm{pH}} \mathrm{p}$ diagrams generated using StabCal. Previously, it was determined that arsenic could be selectively leached under alkaline conditions at an average solution potential of $-300 \mathrm{mV}$, across the $\mathrm{pH}$ range 11-13. Operating under such conditions allowed for selective leaching of arsenic with elemental sulfur formation. From several of the voltammograms obtained during this current testing, the formation of elemental sulfur appeared at increasingly reducing conditions with increasing sulfide concentration. At high concentrations, copper started to solubilise, possibly as a bisulfide complex, reducing the selectivity of the leach, unlike previous studies. However, the presence of the higher sulfide concentration is also anticipated to prevent passivation by consuming any surface formation of elemental sulfur. This study provides insight into the operating parameters of alkaline sulfide leaching in regards to the selectivity of arsenic, as well as guidance for control of reagents and solution potential and, of course, the need for water treatment afterwards.
\end{abstract}

\section{Introduction}

Environmental limitations on pyrometallurgical processing of arsenic-bearing concentrates have forced operations to consider other solutions. Attempts to hydrometallurgically process enargite $\left(\mathrm{Cu}_{3} \mathrm{AsS}_{4}\right)$ can be dual categorized: the co-dissolution of arsenic and copper under acidic conditions and the selective leaching of arsenic under basic conditions. The authors believe that the selective leaching of arsenic is more amenable because it produces a solid copper phase, preferably chalcocite $\left(\mathrm{Cu}_{2} \mathrm{~S}\right)$ or covellite $(\mathrm{CuS})$ that could then be processed using conventional methods already in place in the copper and gold industries. Potential leaching methods include alkaline sulfide (Achimovicovica et al., 1999; Anderson and Twidwell, 2008a,b; Tongamp et al., 2009 and 2010), hypochlorite (Vinals et al., 2003; Curreli et al., 2005; Mihaljovic et al., 2007), ammoniacal (Gajam and Raghavan, 1983), and acid (Gow et al., 2014b) with or without fine grinding to mechanically activate the enargite surface and increase normally slow leach reaction kinetics (Achimovicovica et al., 1999; Balaz et al., 2000; Balaz and Achimovicova, 2006). In this study, the reactivity of enargite under alkaline sulfide leach conditions was examined.

Alkaline sulfide leaching has been shown to be a viable method in treating copper-ores containing high levels of arsenic and antimony, having been patented and used industrially at the operations of both the Sunshine Mine (Holmes and Coltrinari, 1973; Coltrinari, 1977; Anderson and Twidwell, 2008a,b) and Equity Silver Mine (Dayton, 1982). The process has also been shown to have potential for arsenic removal in colemanite processing (Delfini et al., 2003) and Waelz zinc oxide treatment ( $\mathrm{Li}$ et al., 2011). Alkaline sulfide has the advantage of being selective for arsenic 
and antimony, under atmospheric conditions $\left(\sim 100^{\circ} \mathrm{C}\right)$ while producing a solid copper sulfide that can be processed more traditionally (Anderson and Twidwell, 2008a,b).

Arsenic and copper-arsenic sulfides such as orpiment $\left(\mathrm{As}_{2} \mathrm{~S}_{3}\right)$, enargite and tennantite $\left(\mathrm{Cu}_{12} \mathrm{As}_{4} \mathrm{~S}_{13}\right)$ are solubilized as thioarsenite $\left(\mathrm{AsS}_{3}{ }^{3-}\right)$ and thioarsenate $\left(\mathrm{AsS}_{4}{ }^{3-}\right)$ according to Equations 1-3 (Filippou et al., 2007):

$$
\begin{array}{ll}
\mathrm{As}_{2} \mathrm{~S}_{3}+3 \mathrm{~S}^{2-} \rightarrow 2 \mathrm{AsS}_{3}{ }^{3-}(\mathrm{aq}) & \text { Eq. } 1 \\
2 \mathrm{Cu}_{3} \mathrm{AsS}_{4}+3 \mathrm{~S}^{2-} \rightarrow 3 \mathrm{Cu}_{2} \mathrm{~S}(\mathrm{~s})+2 \mathrm{AsS}_{4}{ }^{3-}(\mathrm{aq}) & \text { Eq. } 2 \\
\mathrm{Cu}_{12} \mathrm{As}_{4} \mathrm{~S}_{13}+10 \mathrm{~S}^{2-} \rightarrow 7 \mathrm{Cu}_{1.714} \mathrm{~S}(\mathrm{~s})+4 \mathrm{AsS}_{4}{ }^{3-}(\mathrm{aq}) & \text { Eq. } 3
\end{array}
$$

As indicated, orpiment completely solubilizes and, depending on the type of copper mineral being leached, either chalcocite $\left(\mathrm{Cu}_{2} \mathrm{~S}\right)$ or an anilite-like $\left(\mathrm{Cu}_{1.714} \mathrm{~S}\right)$ phase forms. However, it is understood that covellite $(\mathrm{CuS})$ and other nonstoichiometric copper sulfides $\left(\mathrm{Cu}_{\mathrm{x}} \mathrm{S}\right)$ may form as well, depending on the redox chemistry of the system (Woods et al., 1987). The antimony sulfosalt series, stibnite $\left(\mathrm{Sb}_{2} \mathrm{~S}_{3}\right)$ and tetrahedrite $\left(\mathrm{Cu}_{12} \mathrm{Sb}_{4} \mathrm{~S}_{13}\right)$ are known to behave relatively similarly (Awe and Sandstrom, 2010).

Several recent studies have improved upon the kinetics of arsenic leaching by mechanical activation of concentrates (Achimovicovica et al., 1999; Balaz et al., 2000; Balaz and Achimovicova, 2006). In this case, ultrafine comminution increases the surface area thereby enhancing the rate-determining surface reaction and yielding near-complete removal of arsenic within ten minutes of leaching as opposed to several hours. These studies also reported the formation of both solid and aqueous copper sulfide products, but were focused on how quickly the arsenic dissolved and not on identifying them.

Previous studies (Nadkarni and Kusik, 1988; Anderson and Twidwell, 2008a,b; Tongamp et al., 2010) have indicated the necessity of strict $\mathrm{pH}$ control when dealing with sulfide $\left(\mathrm{S}^{2-}\right)$ in order to limit the amount of hydrolysis and therefore the formation of bisulfide (HS ${ }^{-}$) which appears to slow and even prevent further leaching. They argue that operating conditions must be kept above $\mathrm{pH}$ 13 , noting that these conditions are where sulfide ions predominate. However, it is noted that this transition brings to question the free energy of formation of the sulfide ion: $85.8 \mathrm{~kJ} / \mathrm{mol}$ according to the National Bureau of Standards (NBS) (Wagman et al., 1982) database or $111.4 \mathrm{~kJ} / \mathrm{mol}$ according to the MINTEQA2 (Allison et al., 1990) database used in this study. Using the Minteq value, bisulfide theoretically predominates up to $\mathrm{pH} 17$ and various polysulfides $\left(\mathrm{S}_{\mathrm{x}}{ }^{2-}\right)$ species exist at slightly oxidizing conditions as shown in Figure 1. In accordance with the conclusion of the previous studies (Gow et al, 2014a,b), this $\mathrm{E}_{\mathrm{H}-\mathrm{pH}}$ diagram only considers sulfide oxidation to elemental sulfur thereby excluding the formation of all sulfoxy species (e.g., thiosulfate, $\mathrm{S}_{2} \mathrm{O}_{3}{ }^{2-}$; sulphite, $\mathrm{SO}_{3}{ }^{2-}$; and sulfate, $\mathrm{SO}_{4}{ }^{2}$ ).

Contrary to these proposed reactions, a recent characterization of an alkaline sulfide leach residue (Torres, 2011) has indicated the formation of other copper sulfide species. Digenite $\left(\mathrm{Cu}_{9} \mathrm{~S}_{5}\right)$ and covellite were identified after six hours, while $97 \%$ of the arsenic was leached. Bornite $\left(\mathrm{Cu}_{5} \mathrm{FeS}_{4}\right)$ was also identified due to the high pyrite content in the head sample. Further leaching, up to 24 hours, indicated near complete transformation of the solid species to a soluble sodium copper sulfide identified as $\mathrm{NaCu}_{5} \mathrm{~S}_{3}$, perhaps the same undetermined species reported by Achimovicovica (1999), Balaz (2000) and Balaz and Achimovicova (2006) by mechanical activation. 
The finding of a soluble copper sulfide phase is supported by the theoretical modelling put forth by Young (2003). Under conditions that would be found in an alkaline sulfide leach, copper is solubilized by excess bisulfide. The proposed copper thio-complexes are seen in the proposed $\mathrm{E}_{\mathrm{H}}-$ pH diagram (see Figure 2). Covellite and chalcocite have the potential to be dissolved by excess bisulfide in solution. In this regard, there seems to be a conflict about whether bisulfide enhances leaching or slows/stops the reaction as just mentioned (Nadkarni and Kusik, 1988; Anderson and Twidwell, 2008a,b; Tongamp et al., 2010).

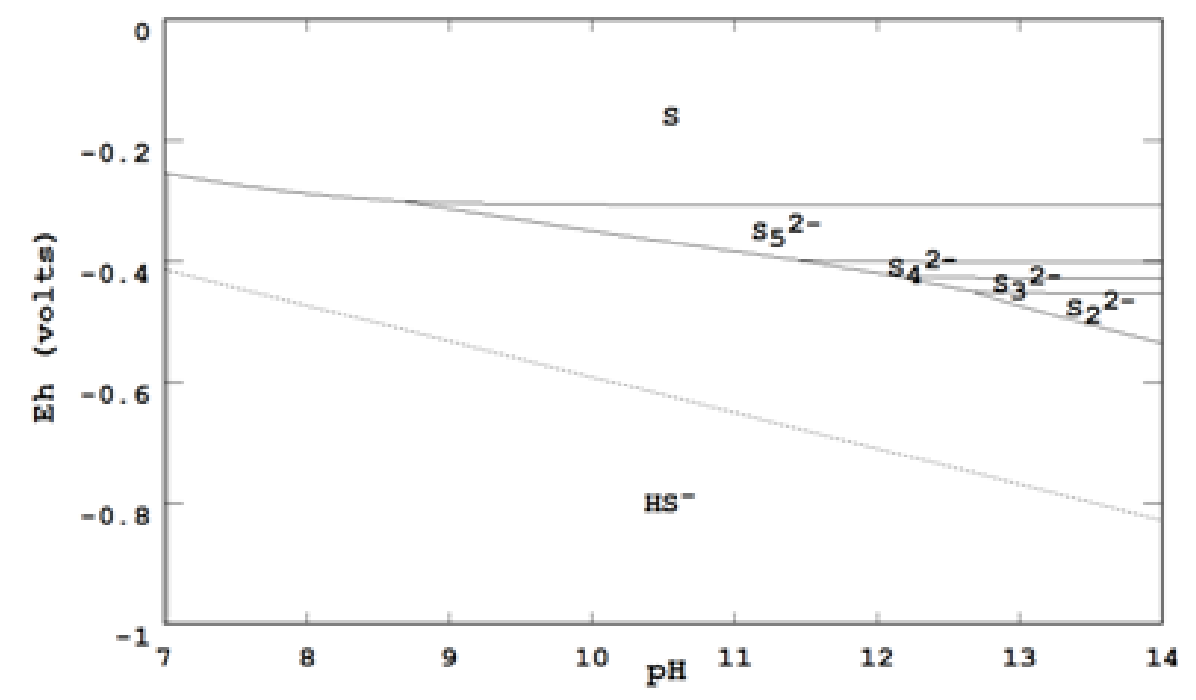

Figure 1 - $\mathrm{E}_{\mathrm{H}-\mathrm{pH}}$ Diagram for Sulfur, 1M, using MinteqThermodynamic Data and Assuming Oxidation to Elemental Sulfur Only Ignoring all Sulfoxy Ions

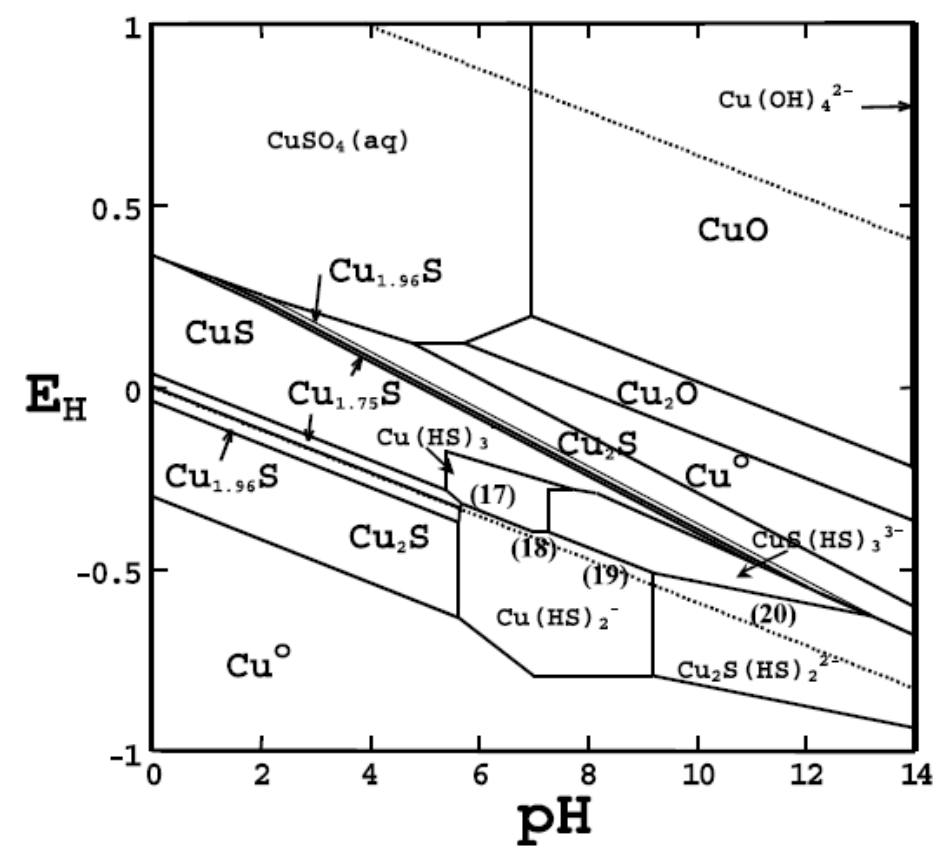

Figure 2 - $\mathrm{EH}_{\mathrm{H}}-\mathrm{pH}$ Diagram for the $\mathrm{Cu}-\mathrm{S}-\mathrm{H}_{2} \mathrm{O}$ system, considering all copper thio-complexes. $\mathrm{Cu}=10^{-5} \mathrm{M}$, $\mathrm{S}=1 \mathrm{M}$ (Young et al, 2003)

In this study, spectroelectrochemical investigations using Raman spectroscopy and cyclic voltammetry on enargite under alkaline and acidic conditions (Gow et al, 2014a,b) are extended 
to alkaline sulfide leaching. The objectives are to increase the reactivity of enargite by improving the reaction kinetics or arsenic selectivity. This is accomplished by comparing Raman spectra and cyclic voltammetry scans over the $\mathrm{pH}$ range 11-13 at room temperature in the absence (Gow et al, 2014a) and presence of $\mathrm{Na}_{2} \mathrm{~S}$.

\section{Thermodynamics}

The free energy database used to calculate the mass-balanced diagrams for enargite (Gow et al., 2014a) was updated to include the soluble arsenic and copper thio-complexes (Young et al., 2000; Young et al., 2003). New mass-balanced $\mathrm{E}_{\mathrm{H}} \mathrm{pH}$ diagrams were calculated using StabCal (Huang and Young, 1996; Huang, 2005; Huang et al., 2011) at $10^{-3}, 10^{-5}$ and $10^{-7} \mathrm{M}$ concentration values for copper and arsenic, in the presence of high sulfide concentrations of 50 and $250 \mathrm{~g} / \mathrm{L}$. The proposed diagrams are shown in Figures 3 and 4. Shaded areas predict regions of copper and arsenic dissolution. Selective arsenic leaching is shown to occur when the sulfur to copper molar ratio is at 640:1 (see Figures 3A,B). At or below this ratio, only arsenic should solubilize, leaving behind the copper as either chalcocite or covellite. At higher ratios, the copper predominantly solubilizes as bisulfide complexes. Hence, as the sulfur content increases relative to the amount of copper, the stability regions of covellite and chalcocite shrink. The remaining region of covellite stability, above $-200 \mathrm{mV}$, corresponds with the region of elemental sulfur formation determined in the previous alkaline reactivity testing (Gow et al., 2014a). Leaching must therefore be done at lower potentials. The region of thioarsenate, $\mathrm{AsS}_{4}{ }^{3-}$, stability is seemingly unchanged across the stability diagrams, suggesting that the $\mathrm{Cu} / \mathrm{S}$ ratio is important to selectively leaching arsenic.

Table 1: Free Energy Values for Copper and Arsenic Thio-complexes

('Young et al., 2000; ${ }^{2}$ Young et al., 2003)

\begin{tabular}{|c|c|c|c|}
\hline $\mathbf{C u ~ S p e c i e s ~}^{2}$ & $\boldsymbol{\Delta G}$ (kcal) & As Species $^{1}$ & $\Delta \mathbf{G}$ (kcal) \\
\hline $\mathrm{Cu}(\mathrm{HS})_{2}{ }^{-}$ & -5.68 & $\mathrm{AsS}(\mathrm{OH})(\mathrm{HS})^{-}$ & -58.58 \\
\hline $\mathrm{Cu}_{2} \mathrm{~S}(\mathrm{HS})_{2}{ }^{2-}$ & -8.11 & $\mathrm{AsS}(\mathrm{HS})_{2}{ }^{-}$ & -9.08 \\
\hline $\mathrm{CuHS}^{0}$ & -2.85 & $\mathrm{As}_{3} \mathrm{~S}_{5}(\mathrm{HS})^{2-}$ & -25.33 \\
\hline $\mathrm{Cu}(\mathrm{HS})_{3}{ }^{-}$ & -11.94 & $\mathrm{HAs}_{3} \mathrm{~S}_{4}(\mathrm{HS})_{2}$ & -43.02 \\
\hline $\mathrm{CuS}(\mathrm{HS})_{3}{ }^{3-}$ & -0.85 & $\mathrm{As}_{3} \mathrm{~S}_{4}(\mathrm{HS})_{2}{ }^{-}$ & -33.22 \\
\hline
\end{tabular}

\section{Sample Analysis}

Electrodes were created from enargite minerals obtained from mines in Butte, MT, USA and Quirivilca, Peru. Sections of the mineral were cut and shaped into approximate $1 / 2$ " $\mathrm{x} 1 / 2$ " pieces and attached to copper wire using Electrodag 502 and carbon tape. They were placed into PTFE tubing and sealed with a non-conducting epoxy resin. Sample compositions were primarily enargite, with small amounts of silica and pyrite, as previously determined by X-ray Diffraction (XRD) and Scanning Electron Microscopy/Mineral Liberation Analysis (SEM/MLA) (Gow et al., 2014a,b). 

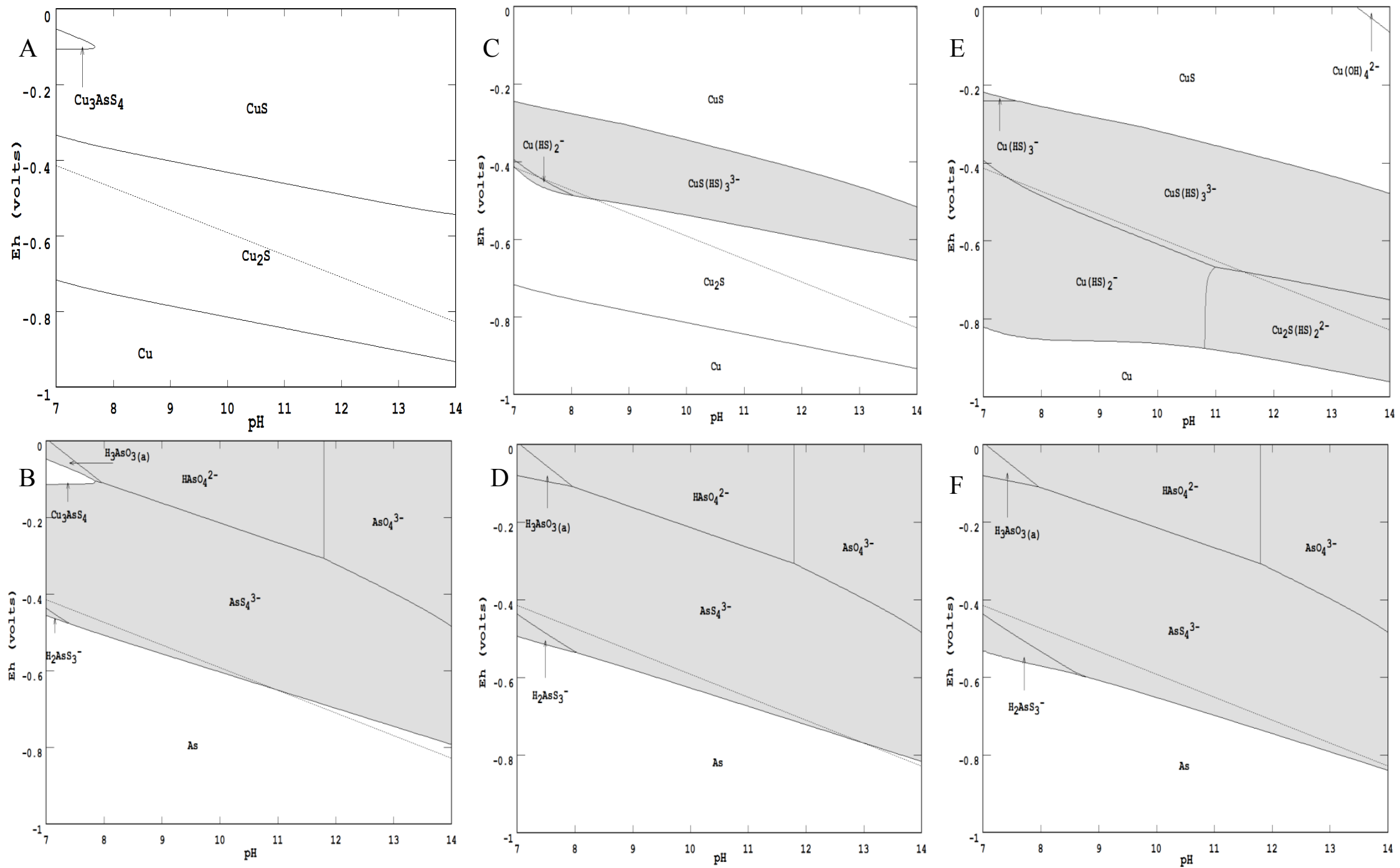

Figure 3: Mass-balanced $\mathrm{E}_{\mathrm{H}} \mathrm{pH}$ Diagrams for the Cu-As-S system, $50 \mathrm{~g} \mathrm{~L}^{-1} \mathrm{Na}_{2} \mathrm{~S}$. Top row shows copper-bearing species while the bottom row shows arsenic-bearing species. Shaded regions indicate where dissolution occurs.
$\mathrm{A} \& \mathrm{~B}) \mathbf{1 0}^{-3} \mathrm{M} \mathrm{Cu} / \mathrm{As}$
$\mathrm{C} \& \mathrm{D}) 10^{-5} \mathrm{M} \mathrm{Cu} / \mathrm{As}$
$\mathrm{E} \& \mathrm{~F}) 10^{-7} \mathrm{M} \mathrm{Cu} / \mathrm{As}$ 

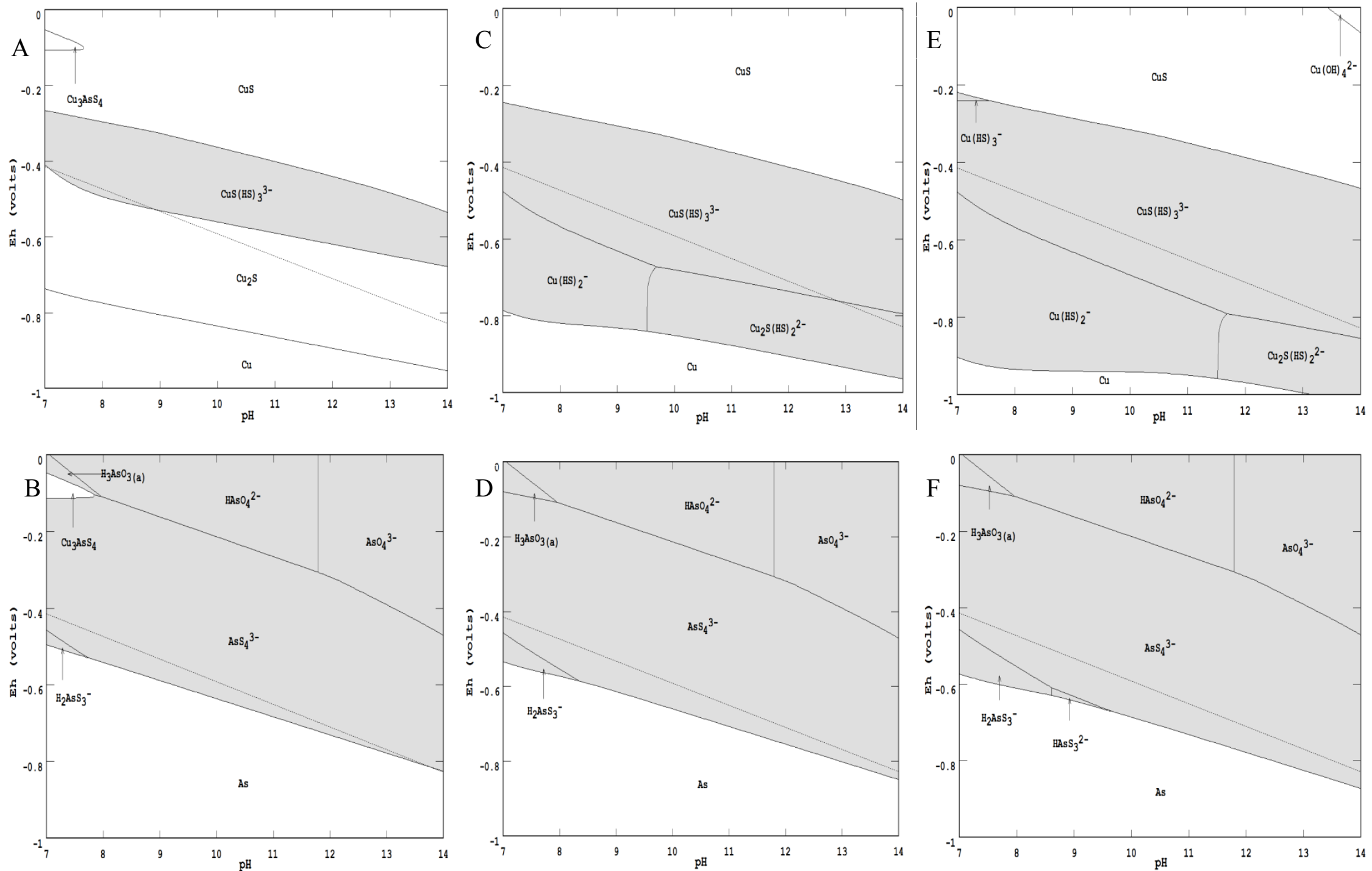

Figure 4: Mass-balanced Eн-pH Diagrams for the Cu-As-S system, $250 \mathrm{~g} \mathrm{~L}^{-1} \mathrm{Na}_{2} \mathrm{~S}$. Top row shows copper-bearing species while the bottom row shows arsenic-bearing species. Shaded regions indicate where dissolution occurs. $\begin{array}{lll}\mathrm{A} \& \mathrm{~B}) 10^{-3} \mathrm{M} \mathrm{Cu} / \mathrm{As} & \left.\mathrm{C} \& \mathrm{D}) 10^{-5} \mathrm{M} \mathrm{Cu} / \mathrm{As} \quad \mathrm{E} \& \mathrm{~F}\right) 10^{-7} \mathrm{M} \mathrm{Cu} / \mathrm{As}\end{array}$ 


\section{Raman Spectroscopy}

In-situ Raman Spectroscopy studies were conducted using a Renishaw Raman 100 InVia spectrophotometer. The system used a $100-\mathrm{mW}$ He-Ne laser excitation source $(632.8 \mathrm{~nm})$ and was calibrated using the $520 \mathrm{~cm}^{-1}$ primary band of pure silicon. Spectral manipulation was conducted using the GRAMS32 software. Details are presented in the previous publications (Gow et al., 2014a,b).

Buffer solutions were created for $\mathrm{pH}$ values 11 (sodium bicarbonate), 12 and 13 (potassium chloride), made according to the CRC Handbook (Haynes, 2011). Sodium sulfide $\left(\mathrm{Na}_{2} \mathrm{~S}\right)$ was added to each buffer solution yielding concentrations of either 50 or $250 \mathrm{~g} \mathrm{~L}^{-1}$. Sulfide concentration levels were identified from other similar studies (Nadkarni and Kusik, 1988; Awe and Sandstrom, 2010; Tongamp et al., 2009).

Raman spectroscopic profiling of the enargite electrode surface has been conducted in previous studies (Gow et al., 2014a,b). The characteristic peaks of potential surface formations were tabulated and reported there, and were used to determine potential surface formations during several static surface tests, where the solution potential was held constant for several minutes.

Chalcocite and covellite were the primary species identified during testing in agreement with the previous studies (Gow et al., 2014a,b). However, during tests with $250 \mathrm{~g} \mathrm{~L}^{-1} \mathrm{Na}_{2} \mathrm{~S}$ solutions, a series of new peaks formed that were not identified. An example is shown in Figure 5 such that peaks at $445,470,985,1000$ and $1070 \mathrm{~cm}^{-1}$ were observed at $-300 \mathrm{mV}$. Because these peaks were similar to the polysulfide peaks observed by Janz et al. (1976a,b,c), $50 \mathrm{~mL}$ of solution was collected from the electrochemical cell and evaporated using dry $\mathrm{N}_{2}$ gas. A Raman spectrum was taken of the resulting evaporate and, as also illustrated in Figure 5, the same peaks were observed although slightly shifted to $446,495,990,1005$ and $1070 \mathrm{~cm}^{-1}$. In addition, a new peak appeared at $955 \mathrm{~cm}^{-1}$. Clearly, under these conditions, some copper is dissolving as predicted in Figure 4 for enargite at $250 \mathrm{~g} \mathrm{~L}^{-1}$.

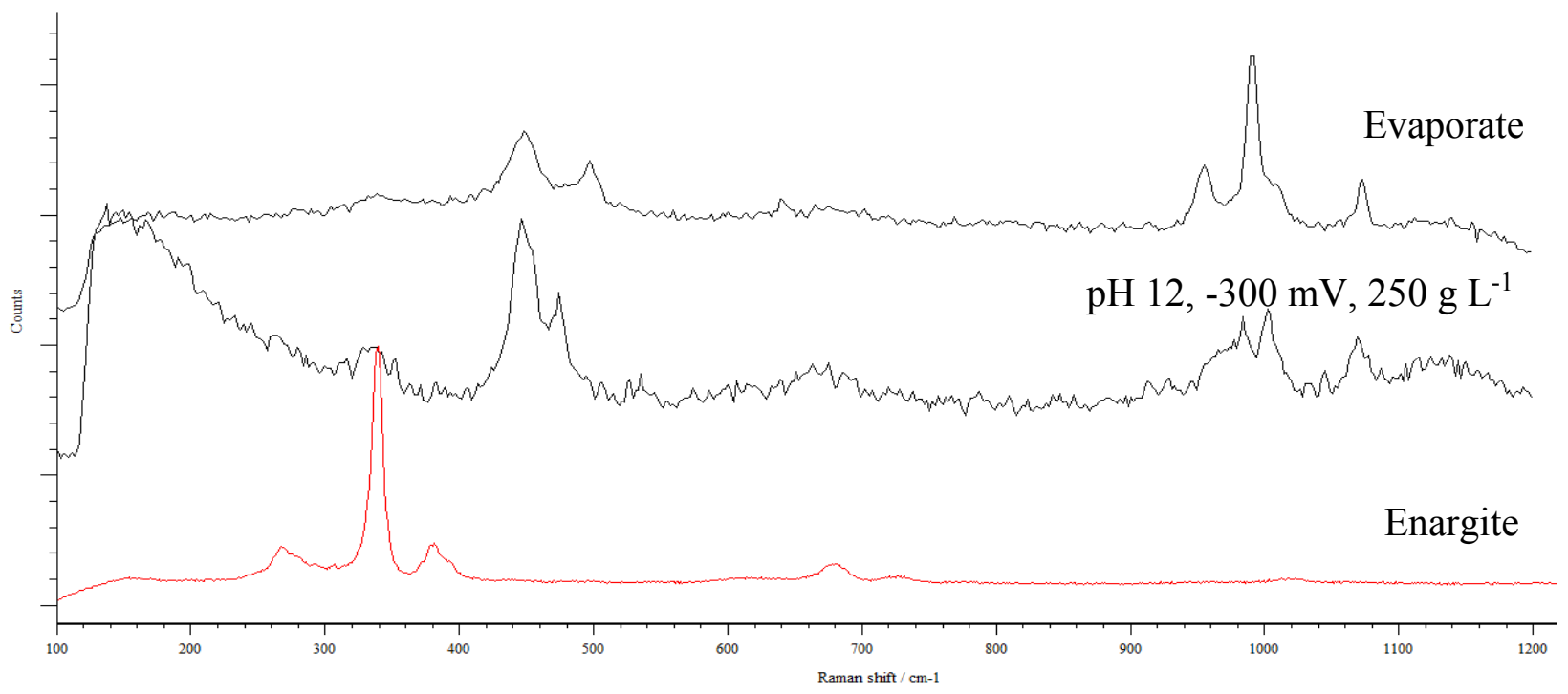

Figure 5 - Raman spectra of enargite (bottom) compared to enargite reacted at $\mathrm{pH} 12$ and $-300 \mathrm{mV}$ with 250 $\mathrm{g} \mathrm{L}^{-1} \mathrm{Na}_{2} \mathrm{~S}$ (middle) and resulting evaporate crystallized out of solution (top) 
At $\mathrm{pH} 12$ and $250 \mathrm{~g} \mathrm{~L}^{-1} \mathrm{Na}_{2} \mathrm{~S}$, Figure 4 predicts that enargite will dissolve as $\mathrm{CuS}(\mathrm{HS})_{3}{ }_{3}{ }^{3-}, \mathrm{Cu}_{2} \mathrm{~S}(\mathrm{HS})_{2}{ }^{2-}$ or $\mathrm{Cu}(\mathrm{HS})_{3}{ }^{-}$and, when the potential is $-300 \mathrm{mV}, \mathrm{CuS}(\mathrm{HS})_{3}{ }^{3-}$ is expected to predominate. Upon evaporation, these species would crystallize out, perhaps as the aqueous copper sulfide identified as $\mathrm{NaCu}_{5} \mathrm{~S}_{3}$ by Torres (2011). Furthermore, based on the spectra obtained in previous studies (Gow et al., 2014a,b; Janz et al., 1976a,b,c), the unknown peaks are not characteristic of covellite or chalcocite. They also do not match the Raman spectra of nonstoichiometric copper sulfides found in the RRUFF database $\left(\mathrm{Cu}_{1.94} \mathrm{~S}\right.$ - djurleite, $\mathrm{Cu}_{1.8} \mathrm{~S}$ - digenite, $\mathrm{Cu}_{1.78} \mathrm{~S}$ - roxbyite, $\mathrm{Cu}_{1.75} \mathrm{~S}-$ anilite, and $\mathrm{Cu}_{1.2} \mathrm{~S}$ - yarrowite).

In this regard, the solution conditions used by previous authors (Nadkarni and Kusik, 1988; Achimovicovica et al, 1999; Curreli, 2009, Anderson and Twidwell, 2008a,b; Tongamp, 2009, Torres, 2011) are compiled in Table 2. $\mathrm{Na}_{2} \mathrm{~S}$ concentrations are close to those used to calculate the $\mathrm{E}_{\mathrm{H}-\mathrm{pH}} \mathrm{diagrams}$ in Figures 3 and 4. Also included in Table 2 is the stoichiometry of the solid copper-sulfide that was produced in each study. Clearly, the stoichiometry of the copper sulfide span between that of chalcocite and covellite, $\mathrm{Cu}_{\mathrm{x}} \mathrm{S}$ (where $2 \leqq \mathrm{x} \leqq 1$ ), and specifically yield values for " $x$ " of 1, 1.4, 1.52, 1.8 and 2. Consequently, there does not seem to be a correlation between leaching conditions and the final product. Rather, it is likely a function of $\mathrm{E}_{\mathrm{H}}, \mathrm{pH}$ and possibly the presence of other minerals.

Table 2: Leaching Conditions used by Previous Authors (adapted from Torres, 2011)

\begin{tabular}{|c|c|c|c|c|c|c|}
\hline Author & $\begin{array}{l}\% \mathrm{Cu} \text { in } \\
\text { Material }\end{array}$ & $\begin{array}{c}\text { Highest } \\
\text { conc. Na2S } \\
\left(\mathrm{g} \mathrm{L} \mathrm{L}^{-1}\right)\end{array}$ & $\begin{array}{l}\text { Amount } \\
\text { solids tested } \\
\left(\mathrm{g} \mathrm{L}^{-1}\right)\end{array}$ & $\begin{array}{c}\text { Maximum } \\
\text { S/Cu Ratio } \\
\text { Observed }\end{array}$ & $\begin{array}{l}\mathrm{NaOH} \\
\text { conc. } \\
\left(\mathrm{g} \mathrm{L}^{-1}\right)\end{array}$ & $\begin{array}{l}\text { Copper } \\
\text { Sulfide } \\
\text { Product }\end{array}$ \\
\hline $\begin{array}{c}\text { Achimovicova et al. } \\
\text { (1999) }\end{array}$ & 39 & 100 & 4 & 52 & 50 & $\mathrm{Cu}_{1.4} \mathrm{~S}$ \\
\hline $\begin{array}{c}\text { Anderson and } \\
\text { Twidwell }(2008 \mathrm{a}, \mathrm{b})\end{array}$ & 18 & 100 & 250 & 2 & 20 & - \\
\hline Curreli (2009) & 33 & 33 & 10 & 8 & 100 & $\begin{array}{c}\mathrm{Cu}_{1.52} \mathrm{~S} \\
\mathrm{Cu}_{2} \mathrm{~S}\end{array}$ \\
\hline $\begin{array}{l}\text { Gow et al. } \\
\text { (this study) }\end{array}$ & $\begin{array}{c}44 \\
(\mathrm{avg})\end{array}$ & 250 & electrode & --- & $\begin{array}{c}\mathrm{pH} \\
11-13\end{array}$ & $\mathrm{CuS}, \mathrm{Cu}_{2} \mathrm{~S}$ \\
\hline $\begin{array}{c}\text { Nadkarni and Kusik } \\
(1988)\end{array}$ & 25 & 160 & 363 & 2 & 1.5 & $\mathrm{Cu}_{2} \mathrm{~S}$ \\
\hline Tongamp (2009) & 33.7 & 200 & 100 & 5 & 50 & $\mathrm{Cu}_{2} \mathrm{~S}$ \\
\hline Torres (2011) & 32 & 80 & 50 & 4 & $100 *$ & $\begin{array}{l}\mathrm{CuS}, \mathrm{Cu}_{1.8} \mathrm{~S} \\
\mathrm{NaCu}_{5} \mathrm{~S}_{3}(\mathrm{aq})\end{array}$ \\
\hline
\end{tabular}

\section{Cyclic Voltammetry}

Further information was gathered using cyclic voltammetry. An electrochemical cell setup was combined with the Raman 100 to conduct multifile program studies. The 5-port cell had a transparent window and was fitted with $\mathrm{Ag} / \mathrm{AgCl}$ saturated $\mathrm{KCl}$ reference $(+0.197$ vs $\mathrm{SHE})$ and platinum counter electrodes. The multifile program was set up to take Raman spectra of the enargite electrode surface every ten seconds while the electrode was potentially cycled. The electrode was cycled negatively from $0 \mathrm{mV}$ to $-1000 \mathrm{mV}$ vs SHE and back a total of three cycles. 
Cyclic voltammograms (CV's) determined in the presence of $\mathrm{Na}_{2} \mathrm{~S}$ were compared to those determined in its absence (Gow et al., 2014a). An example is shown in Figure 6 for results obtained at $\mathrm{pH}$ 13. Results suggest that reactions appear and/or shift to lower potentials with the increasing addition of $\mathrm{Na}_{2} \mathrm{~S}$. It was determined that, in the absence of $\mathrm{Na}_{2} \mathrm{~S}$, selective arsenic dissolution occurred at an average potential of $-300 \mathrm{mV}$ over the $\mathrm{pH}$ range 11-13 according to the following oxidation reaction:

$$
\mathrm{Cu}_{3} \mathrm{AsS}_{4}+4 \mathrm{H}_{2} \mathrm{O}=3 \mathrm{CuS}+\mathrm{S}^{\mathrm{o}}+\mathrm{AsO}_{4}{ }^{3-}+8 \mathrm{H}^{+}+5 \mathrm{e}^{-}
$$

Elemental sulfur $\left(\mathrm{S}^{\circ}\right)$ appears even though it is not thermodynamically stable. However, its presence passivates the surface and thereby slows the reaction considerably as evidenced by the appearance of only one broad cathodic reaction. In this regard, peak $\mathrm{C}_{1}$ masks all of the other reactions which appear as shoulders, if at all. Because enargite is not stable under these alkaline conditions (Gow et al, 2014b), Reaction $\mathrm{C}_{1}$ is not the reverse of Reaction $\mathrm{A}_{1}$; rather, it is a series of reduction reactions involving the products as previously explained for the absence of $\mathrm{Na}_{2} \mathrm{~S}$.

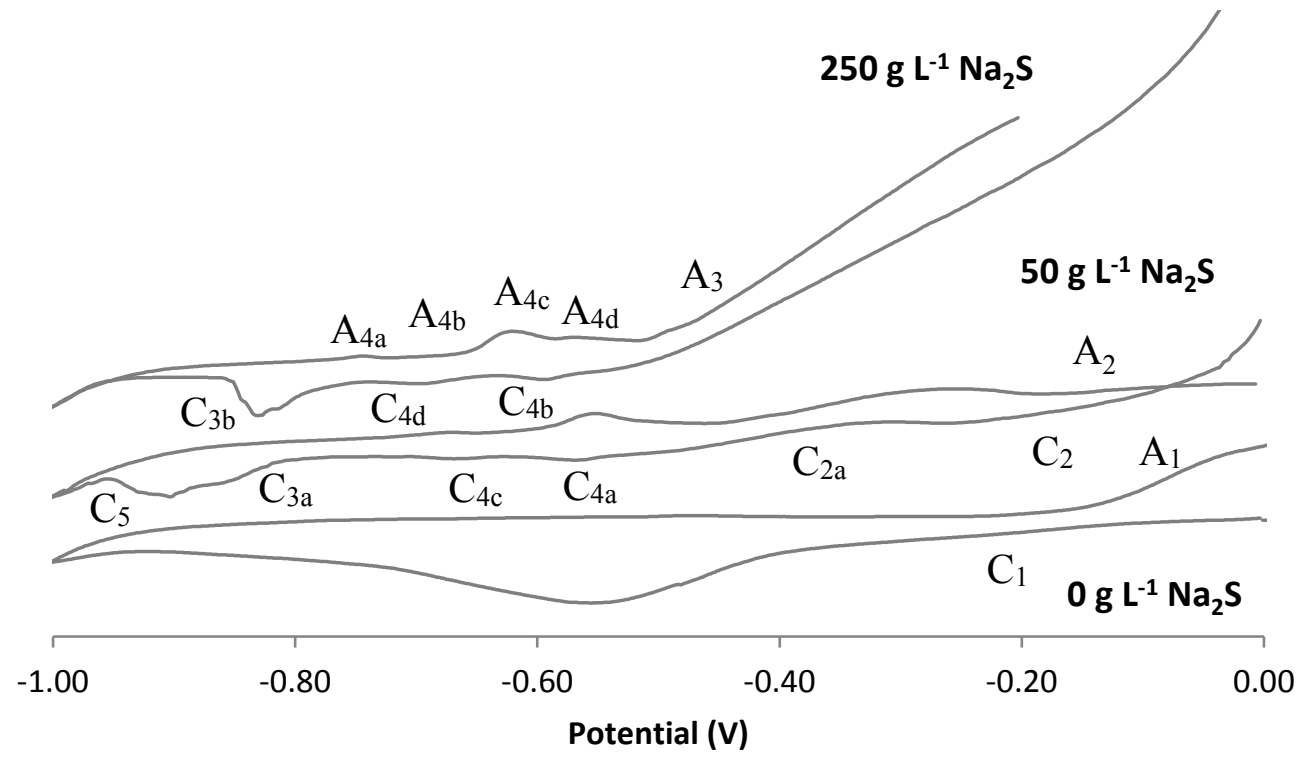

Figure 6 - Cyclic Voltammograms of Enargite at $\mathrm{pH} 13$ in the presence of $250 \mathrm{~g} \mathrm{~L}^{-1} \mathrm{Na}_{2} \mathrm{~S}$ (top) and $50 \mathrm{~g} \mathrm{~L}^{-1}$ $\mathrm{Na}_{2} \mathrm{~S}$ (middle) compared to its absence (bottom). See text for reaction details.

When $\mathrm{Na}_{2} \mathrm{~S}$ is added to the system, it equilibrates with bisulfide $\left(\mathrm{HS}^{-}\right)$and reacts with elemental sulfur to form polysulfide (see Figure 1):

$$
\begin{array}{ll}
\mathrm{S}^{2-}+\mathrm{H}^{+}=\mathrm{HS}^{-} & \text {Eq. } 5 \\
\mathrm{yS}^{\mathrm{o}}+\mathrm{HS}^{-}=\mathrm{S}_{\mathrm{y}^{+1}}{ }^{2-}+\mathrm{H}^{+} & \text {Eq. } 6
\end{array}
$$

where $y=1$ to 4 . Thus, if elemental sulfur forms as with Reaction $A_{1}$, it will be consumed and surface passivation will therefore be prevented. Figure 6 clearly shows that various cathodic reactions are unmasked and, furthermore, that current flow increases with increasing $\mathrm{Na}_{2} \mathrm{~S}$ addition, indicating that reaction rates are indeed enhanced. 
Bisulfide will react with enargite, causing it to oxidize to covellite but, rather than forming arsenate $\left(\mathrm{AsO}_{4}{ }^{3-}\right)$ as in Reaction $\mathrm{A}_{1}$, thioarsenate $\left(\mathrm{AsS}_{4}{ }^{3-}\right)$ will form instead (see Figures 3 and 4$)$ :

$$
\mathrm{Cu}_{3} \mathrm{AsS}_{4}+3 \mathrm{HS}^{-}=3 \mathrm{CuS}+\mathrm{AsS}_{4}^{3-}+3 \mathrm{H}^{+}+3 \mathrm{e}^{-}
$$

Reactions $\mathrm{A}_{1}$ and $\mathrm{A}_{2}$ explain how covellite can be observed in the absence and presence of $\mathrm{Na}_{2} \mathrm{~S}$. Like Reaction $\mathrm{C}_{1}$, the reverse reaction cannot occur because enargite is unstable under these conditions. Reaction $\mathrm{C}_{2}$ therefore involves each of the products undergoing a series of reduction reactions.

\section{$\underline{\mathrm{CuS} \text { Reduction }}$}

If bisulfide is present in significant amounts, it can lower the reducing potential of the solution and cause covellite to reduce to chalcocite and eventually metallic copper:

$$
\begin{aligned}
& 2 \mathrm{CuS}+\mathrm{H}^{+}+2 \mathrm{e}^{-}=\mathrm{Cu}_{2} \mathrm{~S}+\mathrm{HS}^{-} \\
& \mathrm{Cu}_{2} \mathrm{~S}+\mathrm{H}^{+}+2 \mathrm{e}^{-}=2 \mathrm{Cu}^{\circ}+\mathrm{HS}^{-}
\end{aligned}
$$

When covellite and chalcocite form and are exposed to excess bisulfide as well, they will solubilize:

$$
\begin{aligned}
& \mathrm{CuS}+3 \mathrm{HS}^{-}=\mathrm{CuS}(\mathrm{HS})_{3}{ }^{3-} \\
& \mathrm{Cu}_{2} \mathrm{~S}+2 \mathrm{HS}^{-}=\mathrm{Cu}_{2} \mathrm{~S}(\mathrm{HS})_{2}{ }^{2-}
\end{aligned}
$$

Thus, by combining Reactions 8 and 10 as well as Reactions 9 and 11, the following reactions result, respectively:

$$
\begin{array}{lr}
3 \mathrm{CuS}+2 \mathrm{HS}^{-}+\mathrm{H}^{+}+2 \mathrm{e}^{-}=\mathrm{Cu}_{2} \mathrm{~S}+\mathrm{CuS}(\mathrm{HS})_{3}{ }^{3-} & \text { Eq. } 12\left(\mathrm{C}_{2 \mathrm{a}}\right) \\
2 \mathrm{Cu}_{2} \mathrm{~S}+\mathrm{HS}^{-}+\mathrm{H}^{+}+2 \mathrm{e}^{-}=2 \mathrm{Cu}^{\circ}+\mathrm{Cu}_{2} \mathrm{~S}(\mathrm{HS})_{2}{ }^{2-} & \text { Eq. } 13\left(\mathrm{C}_{3 \mathrm{~b}}\right)
\end{array}
$$

It is expected that Reaction $\mathrm{C}_{2 \mathrm{a}}$ occurs at low sulfide addition (i.e., $50 \mathrm{~g} \mathrm{~L}^{-1}$ ) and Reaction $\mathrm{C}_{3 \mathrm{~b}}$ occurs at higher concentrations (i.e., $250 \mathrm{~g} \mathrm{~L}^{-1}$ ). Both reactions explain the formation of the aqueous copper sulfide species observed in this study (see Figure 5) and other studies (Achimovicovica et al., 1999; Balaz et al., 2000; Balaz and Achimovicova, 2006) but perhaps not necessarily yielding the exact $\mathrm{NaCu}_{5} \mathrm{~S}_{3}$ compound observed by Torres (2011).

As mentioned previously, it is understood that covellite may also reduce to form a series of nonstoichiometric copper sulfides before chalcocite is formed (Woods et al., 1987):

$$
\mathrm{xCuS}+\mathrm{xH}^{+}+2 \mathrm{xe}^{-}=\mathrm{Cu}_{\mathrm{x}} \mathrm{S}+\mathrm{xHS}^{-}
$$

where $2 \leqq x \leqq 1$. In this case, the nonstoichiometric copper sulfide will solubilize forming the same products in Reactions $\mathrm{C}_{2 \mathrm{a}}$ and $\mathrm{C}_{3 \mathrm{~b}}$ but dependent on what " $\mathrm{x}$ " is:

$$
\mathrm{Cu}_{\mathrm{x}} \mathrm{S}+\mathrm{a} \mathrm{HS}^{-}+\mathrm{b} \mathrm{H}^{+}+\mathrm{c} \mathrm{e}^{-}=\mathrm{v} \mathrm{Cu}^{\mathrm{o}}+\mathrm{w} \mathrm{CuS}(\mathrm{HS})_{3}{ }^{3-}+\mathrm{z} \mathrm{Cu}_{2} \mathrm{~S}(\mathrm{HS})_{2}{ }^{2-}
$$

This is Reaction $\mathrm{C}_{4}$ and ultimately accounts for the array of peaks that appear in Figure 6 as $\mathrm{C}_{4 a-\mathrm{d}}$ and $\mathrm{A}_{4 \mathrm{a}-\mathrm{d}}$. 
$\underline{\mathrm{AsS}}_{4}{ }^{3-}$ Reduction

According to Figures 3 and 4, $\mathrm{AsS}_{4}{ }^{3-}$ may undergo two reduction reactions, first to $\mathrm{HAsS}_{3}{ }^{2-}$ and then $\mathrm{As}^{0}$ :

$$
\begin{aligned}
& \mathrm{AsS}_{4}{ }^{3-}+2 \mathrm{H}^{+}+2 \mathrm{e}^{-}=\mathrm{HAsS}_{3}{ }^{2-}+\mathrm{HS}^{-} \\
& \mathrm{HAsS}_{3}{ }^{2-}+2 \mathrm{H}^{+}+3 \mathrm{e}^{-}=\mathrm{As}^{\mathrm{o}}+3 \mathrm{HS}^{-}
\end{aligned}
$$

Ah high solution $\mathrm{pH}>8$, it is anticipated this occurs rapidly and the two equations may be combined such that:

$$
\mathrm{AsS}_{4}^{3-}+4 \mathrm{H}^{+}+5 \mathrm{e}^{-}=\mathrm{As}^{\mathrm{o}}+4 \mathrm{HS}^{-}
$$

Although $\mathrm{As}^{\circ}$ was not observed by Raman, its formation could be encompassed in the peaks and shoulders shown in Reactions $\mathrm{C}_{3 \mathrm{a}-\mathrm{b}}$ and possibly masked by Reactions 8 and 13 which correspond to cathodic reactions $\mathrm{C}_{5}$ and $\mathrm{C}_{3}$, respectively. These reactions yield $\mathrm{Cu}^{\circ}$ which occurs near the same potentials as $\mathrm{As}^{\mathrm{o}}$ formation.

\section{Mass Balanced Diagrams}

Mass-balanced $\mathrm{E}_{\mathrm{H}} \mathrm{-pH}$ diagrams are presented in Figure 7A and B, overlaid for copper and arsenic containing species, considering 50 and $250 \mathrm{~g} \mathrm{~L}^{-1} \mathrm{Na}_{2} \mathrm{~S}$ addition, respectively. Inflection points from the CV's are plotted on them to see how thermodynamic predictions match experimental results. In some cases, there is good agreement. However, a majority of the disagreement appear to occur where nonstoichiometric species would be stable. These species were not considered in the StabCal calculations for simplicity purposes but the problem also emanates from not knowing which species would form and its respective free energy data. Of course, reaction kinetics also play a role.
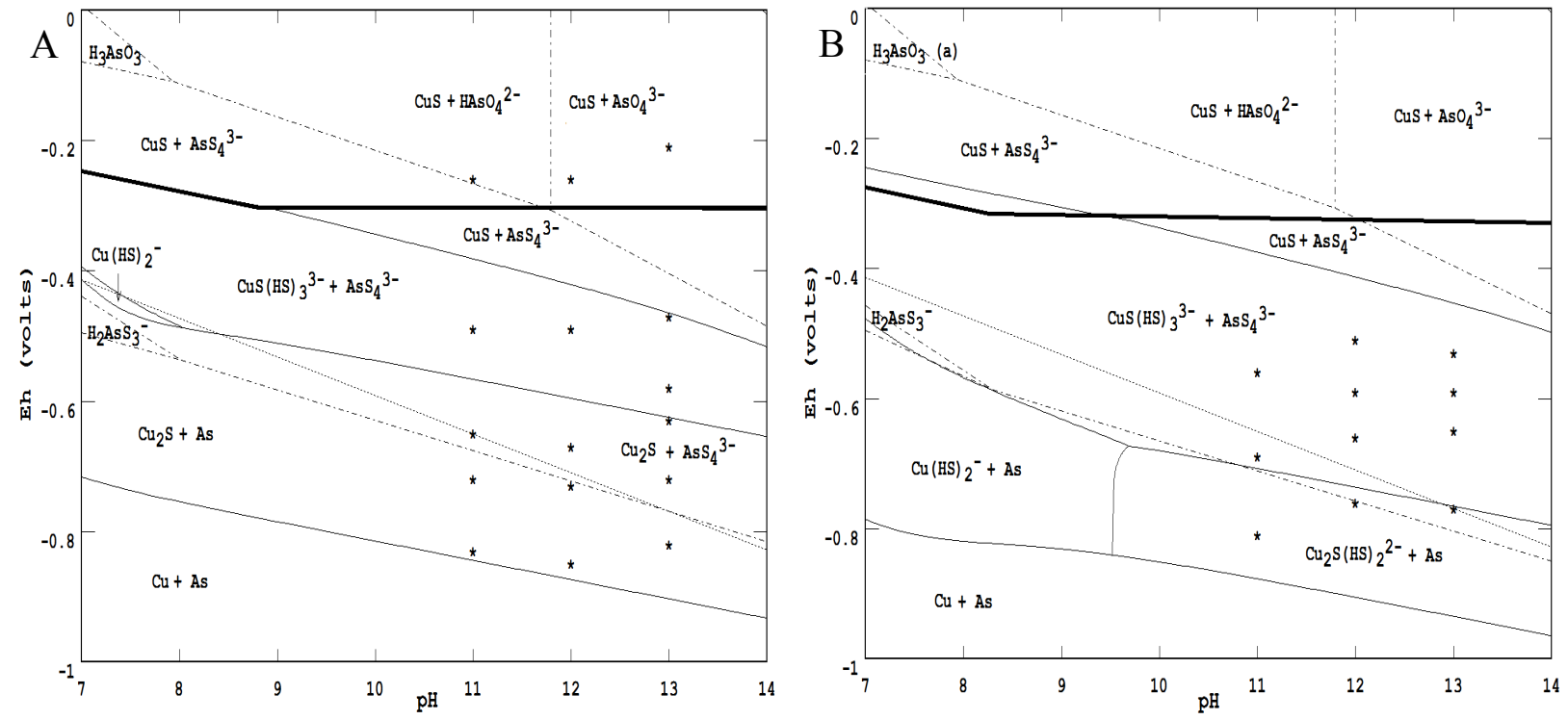

Figure 7- Mass-balanced $\mathrm{E}_{\mathrm{H}-\mathrm{pH}}$ Diagrams for the $\mathrm{Cu}$-As-S system; $3 \times 10^{-5} \mathrm{M} \mathrm{Cu}$ and $1 \times 10^{-5} \mathrm{M}$ As; and $\mathrm{S}$ oxidation to sulfide only with A) $50 \mathrm{~g} \mathrm{~L}^{-1} \mathrm{Na}_{2} \mathrm{~S}$ and B) $250 \mathrm{~g} \mathrm{~L}^{-1} \mathrm{Na}_{2} \mathrm{~S}$. The dotted line indicates the regions of water stability, arsenic-only transitions are indicated by the dashed line, and area above the bolded line indicates stability of elemental sulfur. 


\section{Conclusions}

It is understood that the alkaline sulfide leaching of gold involves conditions similar to those tested here and that sulfide is the likely lixiviant with polysulfide the oxidant that leads to the formation of AuS- (Jeffrey and Anderson, 2003). However, like As and $\mathrm{Cu}$, bisulfide can also leach gold by forming $\mathrm{Au}(\mathrm{HS})_{2}{ }^{-}$(Seward et al., 1973). Aside from these three elements, a number of others are known to form bisulfide complexes: Ag, Pt, Pd, Zn, Hg and Sb (Barnes, 1997). While most of the early interest has been on developing thermodynamic data to understand how metals are transported and deposited geologically, recent applications have been about developing hydrometallurgical processes for extracting and recovering the metals.

For enargite, results have shown that arsenic can be selectively leached but several factors need to be considered. The first involves controlling sulfide addition so that arsenic leaching is maximized and copper leaching is negligible. This appears to be related to the $\mathrm{S}: \mathrm{Cu}$ molar ratio and thermodynamic calculations suggest this ratio should be $640: 1$ explaining why the $\mathrm{Na}_{2} \mathrm{~S}$ of $50 \mathrm{~g} \mathrm{~L}^{-}$ ${ }^{1}$ did not appear to cause $\mathrm{Cu}$ leaching whereas $250 \mathrm{~g} \mathrm{~L}^{-1}$ did. The second involves controlling the $\mathrm{E}_{\mathrm{H}-\mathrm{pH}}$ conditions. Gow et al. (2014a) determined that, in the absence of $\mathrm{Na}_{2} \mathrm{~S}$ addition, selective alkaline leaching could be done between $\mathrm{pH} 11-13$ and $\mathrm{E}_{\mathrm{H}}-600$ to $-300 \mathrm{mV}$. The results of this study in the presence of $\mathrm{Na}_{2} \mathrm{~S}$ has shown that the $\mathrm{E}_{\mathrm{H}}$ range of arsenic solubility has been extended to a region between -800 to $-300 \mathrm{mV}$. The upper range is similar due to elemental sulfur stability; however reactions with $\mathrm{HS}^{-}$and $\mathrm{S}_{\mathrm{y}}{ }^{2-}$ (Reaction 6) are anticipated to prevent surface passivation. The lower range decreased because the stability region of $\mathrm{AsS}_{4}{ }^{3-}$ was enhanced from $-600 \mathrm{mV}$ to $-800 \mathrm{mV}$ due to reaction with $\mathrm{HAsS}_{3}{ }^{2-}$ (Reaction 17). Furthermore, the $\mathrm{pH}$ range could theoretically be lowered to approximately $\mathrm{pH}$ 9. Enargite stability decreased from $\mathrm{pH} 11$ to this value. The third involves treating the resulting alkaline sulfide solution to remove the arsenic and recycle the solution for further use.

The reactivity of an enargite mineral electrode was investigated spectroelectrochemically under conditions typically found during an alkaline sulfide leach, $\mathrm{pH} 11-13$ and $\mathrm{Na}_{2} \mathrm{~S}$ additions of 50 and $250 \mathrm{~g} \mathrm{~L}^{-1}$. A Raman spectrometer was used to determine and compare surface species against massbalanced $\mathrm{E}_{\mathrm{H}-\mathrm{pH}} \mathrm{diagrams}$ generated by StabCal. Previously, it was determined that arsenic could be selectively leached at an average solution potential of $-300 \mathrm{mV}$. Operating under these conditions allowed for selective leaching of arsenic and prevented elemental sulfur formation. From several of the CV's obtained during the current testing, the formation of elemental sulfur appears at more reducing conditions as the sulfide concentration increases. At a high enough concentration, copper starts to leach into solution, reducing the selectivity of the leach.

\section{Acknowledgements}

The authors would like to thank Newmont Mining for their financial support. Mineral samples were provided by DJ Minerals of Butte, MT and Mineral Zone of Tucson, Az.

\section{References}

Achimovicova, M., Balaz, P., Bastl, Z., and Sanchez, M., 1999, "Characterization of the Solid Residue of Enargite $\mathrm{Cu}_{3} \mathrm{AsS}_{4}$ after Alkaline Leaching," Physicochemical Problems of Min. Pro., (33) 7-14.

Allison, J., Brown, D. and Novo-Gradac, K., 1990, "MINTEQA2/PRODEFA2 A Geochemical Assessment Model for Environmental System", Version 3, Environmental Research Laboratory, EPA. 
Anderson, C. and L. Twidwell, 2008a, "Hydrometallurgical Processing of Gold-Bearing Copper Enargite Concentrates," Canadian Metallurgical Quarterly, (47) 337-345.

Anderson, C. and L. Twidwell, 2008b, "The Alkaline Sulfide Hydrometallurgical Separation, Recovery, and Fixation of Tin, Arsenic, Antimony, Mercury and Gold," S. African Inst. Of Min. And Met., 121-132.

Awe S and Sandstrom A., 2010, "Leaching Mechanism of Tetrahedrite in Alkaline Sulfide Solution,” Conference in Minerals Engineering. Luleå, Sweden, 13-24.

Balaz, P. and Achimovicova, M., 2006, "Selective Leaching of Antimony and Arsenic from Mechanically Activated Tetrahedrite, Jamesonite, and Enargite," Int. J. Min. Pro., (81) 44-50.

Balaz, P., Achimovicova, M., Bastl, Z., Ohtani, T., and Sanchez, M., 2000, "Influence of Mechanical Activation on the Alkaline Leaching of Enargite Concentrate," Hydromet, (54) 205216.

Barnes, H.L., 1997, Geochemistry of Hydrothermal Ore Deposits, $3^{\text {rd }}$ Edition, John Wiley \& Sons.

Coltrinari, E.L., 1977, “Sodium Sulfide Leach Process,” U.S. Patent 4,051,220, September 27. (Assigned to Equity Mining Corporation, Canada.)

Curreli, L., Ghiani, M., Surracco, M. and Orru, G., 2005 "Beneficiation of a Gold Bearing Enargite Ore by Flotation and As Leaching with Na-Hypochlorite," Min. Eng., (18) 849-954.

Dayton, S., 1982, "Equity Silver on line with leach plant: How Sb and As are purged from a highsilver copper concentrate before smelting," Min. Eng., (183) 78-83.

Delfini, M., Ferrini, M., Manni, A., Massacci, P., and Piga, L., 2003, “Arsenic Leaching by $\mathrm{Na}_{2} \mathrm{~S}$ to Decontaminate Tailings Coming from Colemanite Processing," Min. Eng., (16) 45-50.

Downs, R., 2006, "The RRUFF Project: an integrated study of the chemistry, crystallography, Raman and infrared spectroscopy of minerals," Program and Abstracts of the 19th General Meeting of the International Mineralogical Association in Kobe, Japan.

Ferron, C. and Wang, Q., 2003, "Copper Arsenide Minerals as a Sustainable Feedstock for the Copper Industry,” SGS Mineral Services Technical Bulletin 2003-15.

Filippou, D., St. Germain, P., and Grammatikopoulos T., 2007, "Recovery of Metal Values from Copper-Arsenic Minerals and Other Related Resources," Min. Proc. \& Extr. Met. Rev., (28) 247298.

Gow, R., Young, C., Huang, H., Hope, G., and Takasaki, Y., 2014a, "Spectroelectrochemistry of Enargite I: Reactivity in Alkaline Solutions," submitted to Min. Met. Proc.

Gow, R., Young, C., Huang, H. and Hope, G., 2014b, "Spectroelectrochemistry of Enargite II: Reactivity in Acidic Solutions," submitted to Min. Met. Proc.

Haynes, W., 2011, CRC Handbook of Chemistry and Physics, 92 ${ }^{\text {nd }}$ Edition, CRC Press. 
Holmes, W.C. and Coltrinari, E.L., 1973, "Process for Removal of Arsenic from Sulfo-ore," U.S. Patent 3,709,680, January 9. (Assigned to Sunshine Mining Company, USA)

Huang, H., 2012, “STABCAL,” Metallurgical \& Materials Engineering, Montana Tech.

Huang, H. and Young, C., 1996, "Mass Balanced Calculations of $\mathrm{E}_{\mathrm{H}-\mathrm{pH}} \mathrm{Diagrams}$ using STABCAL," in Elec trochemistry in Mineral and Metal Processing IV, eds. R. Woods, F. M. Doyle and P. Richardson, The Electrochemical Society Proceedings 96-6, 227.

Huang, H., Twidwell, L. and Young, C., 2005, "Speciation for Aqueous Systems - An Equilibrium Calculation Approach," Proceedings of COM 2005 \& 35th Annual Hydrometallurgical Meeting, Calgary, Canada.

Janz, G., Downey Jr., J., Roduner, E., Wasilczyk, G., Coutts, J. and Eluard, A., 1976a, "Raman Studies of Sulfur-Containing Anions in Inorganic Polysulfides. Barium Trisulfide," Inorg. Chem., (15) $1751-1755$.

Janz, G., Downey Jr., J., Roduner, E., Wasilczyk, G., Coutts, J. and Eluard, A., 1976b, "Raman Studies of Sulfur-Containing Anions in Inorganic Polysulfides. Potassium Polysulfides," Inorg. Chem., (15) 1755-1759.

Janz, G., Downey Jr., J., Roduner, E., Wasilczyk, G., Coutts, J. and Eluard, A., 1976c, "Raman Studies of Sulfur-Containing Anions in Inorganic Polysulfides. Sodium Polysulfides," Inorg. Chem., (15) 1759-1763.

Jeffrey, M. and Anderson, C., 2003, "A Fundamental Study of the Alkaline Sulfide Leaching of Gold" Eur. J. Of Min. Proc. And Env. Prot., (3) 336-343.

Li, Y., Liu, Z., Li, Q., Zhao, Z., Liu, Z., and Zeng, L., 2011, "Removal of Arsenic from Waelz Zinc Oxide using a Mixed NaOH-Na2 ${ }_{2}$ Leach," Hydromet, (108) 165-170.

Mihajlovic, I., Strbac, N., Zivkovic, Z., Kovacevic, R., and Stehernik, M., 2007 “A Potential Method for Arsenic Removal from Copper Concentrates," Min. Eng., (20) 26-33.

Nadkarni, R. and Kusic, C., 1988, "Hydrometallurgical Removal of Arsenic from Copper Concentrates," Arsenic Metallurgy: Fundamentals and Applications, (R.G. Reddy, J.L. Hendrix, and P.B. Queneau, Eds.), Warrendale, PA: The Metallurgical Society, 263-286.

Seward, T.M., 1973, "Thio Complexes of Gold and the Transport of Gold in Hydrothermal Ore Solutions," Geochim. Cosmochim. Acta (37) 379-399.

Shea, D. and Helz, G.R., 1988, "The Solubility of Copper in Sulfide Waters: Sulfide and Polysulfide Complexes in Equilibrium with Covellite," Geochim Cosmochim. Acta, (52) 18151825 .

Shea, D. and Helz, G.R., 1989, "Solubility Product Constants of Covellite and a Poorly Crystalline Copper Sulfide Precipitate at 298 K," Geochim Cosmochim. Acta, (53) 229-236.

Tongamp, W., Takasaki, Y., and Shibiyama, A., 2009, "Arsenic Removal from Copper Ores and Concentrates through Alkaline leaching in NaHS Media," Hydromet., (98) 213-218. 
Tongamp, W., Takasaki, Y., and Shibiyama, A., 2010, "Selective Leaching of Arsenic from Enargite in NaHS-NaOH Media," Hydromet., (101) 64-68.

Torres, F., 2011, "The Alkaline Sodium Sulphide Leaching of Enargite," MSc Thesis, University of British Columbia.

Vinals J., Roca, A., Hernandez M., and Benavente, O., 2003 "Topochemical Transformation of Enargite into Copper Oxide by Hypochlorite Leaching," Hydromet., (68) 183-193.

Wagman, D., Evans, W., Parker, V., Schumm, R., Halow, I., Bailey, S., Churney, K., and Nuttall, R., 1982, "The NBS Tables of Chemical Thermodynamic Properties," National Bureau of Standards, Washington, DC.

Woods, R., Yoon, R. And Young, C., 1987, "Eh-pH Diagrams for Stable and Metastable Phases in the Copper-Sulfur-Water system," Int. J. Min. Proc., (20) 109-120.

Young, C. and Robins, R., 2000, "The Solubility of $\mathrm{As}_{2} \mathrm{~S}_{3}$ in Relation to the Precipitation of Arsenic from Process Solutions," In Minor Elements 2000: Processing and Environmental Aspects of $A s, S b, S e, T e$, and Bi. Edited by Young CA. Society for Mining, Metallurgy, and Exploration.

Young, C.A., Dahlgren, E.J. and Robins, R.G., 2003, "The Solubility of Copper Sulfides under Reducing Conditions," Hydromet, (68) 23-31. 